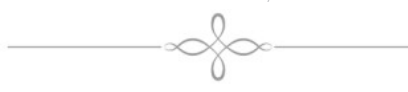

\section{Os novos produtos imobiliários residenciais e as mudanças na organização espacial da cidade de Lajeado - RS}

Resumo: A reestruturação urbana se relaciona com as mudanças da economia em tempos de constantes inovações produtivas e tecnológicas. Tais mudanças têm promovido alterações no modo de produção e na dinâmica de acumulação de capital e ocasionado reflexos na dinâmica de urbanização das cidades, nas mais diferentes escalas. As estratégias e formas de ação do mercado imobiliário, atuando no lançamento de novos produtos imobiliários para moradia se apresenta como geradora das mais importantes mudanças sócio espaciais destas cidades, contribuindo para sua reestruturação. A relação entre mercado imobiliário e a atual estrutura urbana da cidade de Lajeado, na região do Vale do Taquari - Rio Grande do Sul se constitui como o foco principal deste trabalho.

\section{The new residential real estate products and changes in the spatial organization of the city of Lajeado - RS}

\begin{abstract}
Urban restructuring is related to economy changes when there are constant technological and productive changes. Those changes have been responsible for modifications in the productions systems and the dynamics of capital accumulation and when there are reflexes in the cities urbanization, in different scales. The strategies and methods of the real estate market, working on launching new products for real estate property presents as generating the most important changes sociospatial this city, driven by new production strategies, reproduction and capital accumulation. This relationship between the housing market and the current urban structure of the city of Lajeado, in the Vale do Taquari - Rio Grande do Sul, constitutes as the main focus of this work.
\end{abstract}

Eliza Bergamaschi*

Rogério Leandro Lima da Silveira**

* Mestre em Desenvolvimento Regional pela Universidade de Santa Cruz do Sul (UNISC).

** Doutorado em Geografia Humana pela Universidade Federal de Santa Catarina (UFSC). Professor Titular no Departamento de Geografia e História da UNISC.
Palavras-chave:

Reestruturação condomínios residenciais, Lajeado, mercado imobiliário.

Key-Words:

Urban restructuring, residencial condominiums, Lajeado, real estate market. 


\section{Introdução}

A cada novo ciclo econômico e principalmente após a década de 1990 com a flexibilização das relações de trabalho e produção, modificam-se as relações com o território. A abertura econômica aos produtos importados, resultante da adoção de políticas neoliberais introduzidas no governo de Fernando Collor e que tiveram continuidade nos dois mandatos do presidente Fernando Henrique Cardoso, forçaram modificações na estrutura produtiva bem como nas condições e relações de trabalho que tornaram imperativa a reestruturação do território.

Em Lajeado, observa-se mudanças na dinâmica socioespacial deste polo regional como o crescimento populacional, o aumento da urbanização, o lançamento de novos produtos imobiliários, as melhorias nas vias de escoamento de produção e obtenção de matéria prima, a influência nos aspectos socioculturais e a ampliação dos fluxos migratórios. Da mesma forma, o mercado imobiliário se apresenta como indutor de modificações internas na estrutura urbana municipal. Ao lançar no mercado de imóveis inovações locacionais e tipológicas, este setor da economia se torna causador de mudanças nas dinâmicas urbanas regionais.

A atual organização do espaço no caso de Lajeado, na região do Vale do Taquari - RS, se dá no contexto de um município quase que exclusivamente urbano em razão, principalmente, dos processos de emancipações municipais ocorridos na região. Característica desta cidade altamente urbanizada é o direcionamento da sua economia para os setores de comércio e serviços que, através dessa função urbana, alteram as relações intra e interurbanas com as demais cidades da região. $\mathrm{Na}$ cidade de Lajeado, centro regional e foco deste artigo, observa-se além da expansão comercial e da prestação de serviços, a existência de um centro universitário como atrativo populacional e de novos investimentos empresariais, decorrentes do lançamento de novas tecnologias e da mão de obra especializada disponível.

O fato de Lajeado se constituir como uma cidade média se inserindo nas dinâmicas mundiais de reprodução do capital, apresenta a importância de cidades de porte intermediário entre as grandes metrópoles e as cidades pequenas. As cidades médias passaram a se destacar nas redes e conexões urbanas contemporâneas por seu forte papel econômico e social atraindo investimentos que a malha urbana metropolitana não poderia mais abrigar. Este novo papel das cidades de porte médio influenciou a reestruturação do seu espaço urbano para abrigar este novo papel, principalmente sob a influência das estratégias dos agentes formadores do espaço urbano.

Buscando compreender a atual estrutura urbana de Lajeado e o seu processo de formação, estruturamos este artigo em três partes: a primeira traz a tona os conceitos de espaço urbano, reestruturação urbana, cidade média e caracteriza os novos produtos imobiliários; a segunda parte expõe características importantes do município de Lajeado enquanto a terceira e última parte apresenta os novos produtos imobiliários indutores da reestruturação espacial Lajeadense.

\section{Estabelecendo conceitos para a compreensão das novas dinâmicas urbanas de Lajeado}

O estabelecimento de conceitos serve como base para estudos diversos que são aprofundados e relacionados no decorrer da construção do conhecimento. Analisar e relacionar diferentes conceitos faz parte deste processo de aperfeiçoamento.

Os conceitos servem para que seja possível atingir a compreensão de determinados objetos e fenômenos, constituindo-se de um instrumento de conhecimento e pesquisa. Um conceito não se confunde com o real, mas é uma representação desta realidade e por isso só pode ser originado após o acontecimento deste evento ao qual representa (LENCIONI, 2008).

Baseado nestas afirmações, consideramos alguns conceitos como o de espaço urbano, cidade média e novos produtos imobiliários, e a representação das novas dinâmicas do espaço 
urbano Lajeadense, baseados principalmente na sua reestruturação urbana.

A partir do momento em que o homem deixa de ser nômade e passa a se fixar num determinado espaço, uma porção de solo, ele dá início a um processo que vai modificá-lo e reproduzi-lo de acordo com suas necessidades. Modifica-se também sua relação com o meio, pois a sociedade cria novas técnicas para suprir a necessidade de sobrevivência utilizando este espaço por períodos mais longos (CARLOS, 2001).

A relação entre homem e natureza se modifica a partir do processo de trabalho que vai definir o novo espaço, este, derivado do desenvolvimento da sociedade. Este espaço produzido pela sociedade dela se torna inseparável. A reprodução do espaço enquanto produto destas relações sociais tem cunho histórico e carrega consigo as consequências das decisões tomadas em períodos anteriores. Está fortemente relacionado ao cotidiano e se materializa na forma de apropriação e ocupação de determinado lugar num determinado contexto histórico (CARLOS, 2001).

Segundo Correa (1989), o espaço urbano se forma com a sobreposição de interesses que se caracterizam pelos diferentes usos do solo urbano. Esta organização espacial da cidade segundo a possibilidade de acesso e de uso nos apresenta o espaço urbano como um espaço fragmentado, porém articulado. Fragmentado, pois cada fragmento/fração desenvolve suas próprias características, independente do restante da malha urbana. Articulado, pois as diferentes partes deste espaço se relacionam de alguma forma específica.

As relações entre as distintas parcelas do espaço urbano se materializam com a circulação de pessoas, capital e informações que nem sempre são visíveis espacialmente. São relações virtuais, espaciais e sociais que estão baseadas na diferenciação social e de classes. Logo, pode-se afirmar que o espaço urbano, além de ser articulado e fragmentado também é um reflexo da sociedade e das relações entre as diferentes classes sociais. A sociedade capitalista e desigual, materializa no espaço urbano as diferenças sociais dos grupos que ocupam cada espaço de acordo com sua renda e classe social (CORREA, 1989).

Seguindo esta linha de raciocínio, temos então o espaço urbano fragmentado, articulado e reflexo da sociedade. A vida urbana, assim como as relações sociais, se modifica de acordo com as novas dinâmicas espaciais, resultado dos novos interesses dos atores que produzem e modificam o espaço urbano, fazendo com que este espaço também seja mutável e construído ao longo do tempo. O espaço urbano é condicionante e reflexo das relações sociais. É o lugar onde acontecem disputas pelo poder e consequentemente se apresenta como resultado destas lutas sociais. É onde a vida urbana acontece e por esta razão é a representação destas disputas (CORREA, 1989).

\begin{abstract}
O espaço urbano capitalista - fragmentado, articulado, reflexo e condicionante social, cheio de símbolos e campo de lutas - é um produto social, resultado de ações acumuladas através do tempo, e engendradas por agentes que produzem e consomem espaço. São agentes sociais concretos, e não um mercado invisível ou processos aleatórios atuando sobre um espaço abstrato. A ação destes agentes é complexa, derivando da dinâmica de acumulação de capital, das necessidades mutáveis de reprodução das relações de produção, e dos conflitos de classe que dela emergem (CORREA, 1989, p. 11).
\end{abstract}

À medida que a sociedade vai evoluindo e modificando suas relações com o espaço, este enquanto produto destas relações sociais também se modifica e se reestrutura. O espaço urbano precisa se reorganizar para tender as novas demandas, principalmente econômicas que afetam as sociedades das mais diferentes formas e com as mais diversas escalas.

A cada novo ciclo produtivo e econômico a cidade precisa se reestruturar para atender a demanda por atualização e modernização, seja com mudanças sociais, políticas, econômicas ou de produção. Estas mudanças acontecem internamente nas cidades, dentro de seu espaço urbano assim como na relação entre estas e as demais cidades que compõem a região e a rede urbana onde estão inseridas.

Este movimento está articulado à reorganização econômica mundial, sendo que os impactos
Geografia Ensino \& Pesquisa, v. 18, n. 3 p. $07-26$, set./dez. 2014

Bergamaschi, E.; Silveira, R. L. L. da

ISSN 2236-4994 | $\quad 9$ 
territoriais são a materialização/expressão concreta destas mudanças no processo de produção. Tais mudanças não se limitam aos aspectos puramente econômicos, mas também causam transformações espaciais, políticas, sociais, culturais que se manifestam após rupturas que fazem com que se veja a cidade de forma diferente.

No espaço intra-urbano, estas novas técnicas de produção causam marcantes alterações imprimindo novas características aos espaços, aos processos de urbanização, de organização da população, dos fluxos migratórios, do mercado imobiliário, da mesma forma que modificam as funções das cidades e dos lugares no âmbito regional (BAENINGER, 1998).

\begin{abstract}
A evolução da economia internacional, o crescimento espetacular das novas tecnologias de informação e de comunicação e a constituição de poderosas organizações transnacionais ligadas por redes subordinadas e descentralizadas, são fatores decisivos no processo que dá sentido estrutural a cada território, pela função que este desempenha num contexto mais amplo de operações independentes. Continuam certamente a existir formas espaciais, visto que as sociedades e as economias se desenvolvem em territórios concretos e de modo desigual pelo mundo afora. Mas, na ótica das organizações e dos interesses sociais dominantes, a lógica e a dinâmica do desenvolvimento territorial são cada vez mais espaciais (CASTELLS, 1987, p. 7).
\end{abstract}

São mudanças que não estão relacionadas apenas à estrutura urbana e ao conteúdo da dinâmica de reprodução do uso do solo na cidade, mas também estão relacionadas à teia de relações que formam as redes urbanas. É necessário entender a estrutura urbana a partir do processo histórico que a constituiu ao longo do tempo (SANTOS, 2008).

É neste contexto de mudanças nas relações entre as cidades que formam as redes urbanas que se solidifica o papel das cidades médias. A importância de se conceituar as cidades médias surge com a emergência destas cidades não metropolitanas nos cenários econômicos nacional e mundial.

Utilizamos aqui o conceito de cidade média como o formulado por Sposito (2007) e por Correa (2006), quando se referem aquelas cidades que desempenham funções econômicas que lhes atribuem papéis regionais ou de intermediação de fluxos variados no âmbito da rede urbana, sobretudo no atual contexto de ampliação e de complexificação das relações entre as cidades, e entre elas e suas regiões de influência, que se dão em distintos níveis escalares.

Com a saturação da malha urbana das metrópoles que já não conseguem atender a demanda por emprego e vida urbana da população, as empresas desconcentram suas linhas de produção em direção a outras localidades, criando novos pontos de investimento de capital industrial e imobiliário e consequentemente novas centralidades.

A desconcentração industrial não deve ser confundida com descentralização industrial. Na desconcentração industrial, as unidades fabris saem da metrópole em direção as cidades médias, porém a gestão e a tomada de decisões continuam centralizadas nas grandes metrópoles (DAMIANI, 2006).

As cidades médias são uma alternativa de vida às populações. Pela sua dimensão tem as vantagens da urbanização metropolitana sem sofrer as consequências negativas das cidades com grandes dimensões. Adquirem características e vantagens de uma cidade grande, porém sem absorver as desvantagens desta (COSTA, 2002).

Uma das facetas da reestruturação intra-urbana pela qual passam as cidades médias se relaciona ao mercado imobiliário e aos novos produtos lançados no mercado visando atrair compradores e movimentar este ramo da economia.

Os novos produtos imobiliários, destinados para residências e em forma de condomínios disponibilizados na malha urbana das cidades contemporâneas, se apresentam de diversas formas e com diferentes graus de interação social entre os moradores e proprietários destes imóveis. 
Os loteamentos se constituem através do parcelamento de uma gleba de terras em frações menores constituindo lotes. A legislação federal, através da Lei 6766 de 1979 determina que outras frações desta gleba devam ser direcionadas para a construção de vias de circulação pública (ruas e passeios), áreas verdes e áreas institucionais. Tais parcelas passam a fazer parte do espaço público municipal, ao qual também é repassada a responsabilidade pela manutenção destes espaços.

Já os loteamentos fechados se apresentam de forma ilegal perante esta legislação federal. Nestes casos, a justificativa da busca por maior segurança dos moradores incentiva o fechamento dos limites deste empreendimento. São construídos muros e cercas fechando o loteamento e desta forma vetando o acesso aos espaços públicos internos. Se trata de apropriação ilegal de espaços públicos pelos proprietários e moradores dos loteamentos fechados, passando a constituir como espaços privativos estas parcelas urbanas de poder do município e de sua população.

Nos condomínios urbanísticos - outro produto imobiliário contemporâneo - a estratégia é a mesma dos loteamentos fechados, porém de forma legalizada. Uma gleba sofre parcelamento com a instituição de áreas de circulação viária, áreas verdes e institucionais, porém estes espaços continuam privativos. A posse, assim como a responsabilidade pela manutenção destas áreas é seus moradores. Nestes casos, adquire-se o lote como uma unidade privativa e uma fração das demais áreas de uso comum do empreendimento.

Oura versão deste produto são os condomínios fechados, que em Lajeado se apresentam com características bastante marcantes. Basicamente se constituem de casas assobradadas e construídas em fita onde se adquire a edificação pronta. A variação deste produto imobiliário se caracteriza pelo diferente nível de interação entre seus moradores, variando desde os sobrados onde cada unidade é independente, com acesso exclusivo, grades e muros delimitando cada moradia, até os sobrados onde se verifica a existência de áreas de uso comum aos moradores, como salão de festas e piscina coletiva. Neste caso, além da edificação pronta e da sua respectiva fração de lote, se adquire um parcela proporcional das áreas de uso comum do condomínio.

\section{O município de Lajeado}

O município de Lajeado está localizado na região do Vale do Taquari ${ }^{1}$, na parte central do Rio Grande do Sul. (Figura 1). Abrangendo uma área de $4.821,1$ km², possui população de 329.258 pessoas (2011), o que representa 3,06\% de todo Estado (FEEDados, 2013, texto digital).

Os municípios dessa região sofreram inúmeras emancipações, principalmente no período entre 1990 e 2000, quando onze municípios apresentaram perda de território e de população. Neste período foram criados 13 novos municípios fazendo com que a população urbana passasse a predominar sobre a população rural.

No município de Lajeado, a população rural sofreu uma variação bastante significativa, reduzindo significativamente a partir de 1988, ano de aprovação da Constituição Federal. A partir de então, a criação de novos municípios fez com que a população rural sofresse uma redução de 98,43\% em vinte anos. Segundo dados da FEE, Lajeado possui atualmente 71.180 moradores na zona urbana e apensas 265 moradores na sua zona rural.

A densidade demográfica apresentada pelo município de Lajeado no ano de 2010 se apresenta superior ao índice estadual. Com uma distribuição populacional de 790 habitantes/ $\mathrm{km}^{2}$, Lajeado apresenta uma densidade demográfica 20 vezes maior que a média do Rio Grande do Sul. A redução da área rural municipal e o consequente adensamento populacional na zona urbana são os principais motivadores deste índice elevado.
1 A região do Vale do Taquari é composta por 36 municípios e representa uma das 28 regiões de planejamento dos COREDES (Conselhos Regionais de Desenvolvimento), instituídos a partir de 1990 no Estado do Rio Grande do Sul.

Geografia Ensino \& Pesquisa, v. 18, n.3 p. $07-26$, set./dez. 2014.

Bergamaschi, E.; Silveira, R. L. L. da ISSN 2236-4994 


\section{REGIÃO DO VALE DO TAQUARI E MUNICIPIO DE LAJEADO/RS}

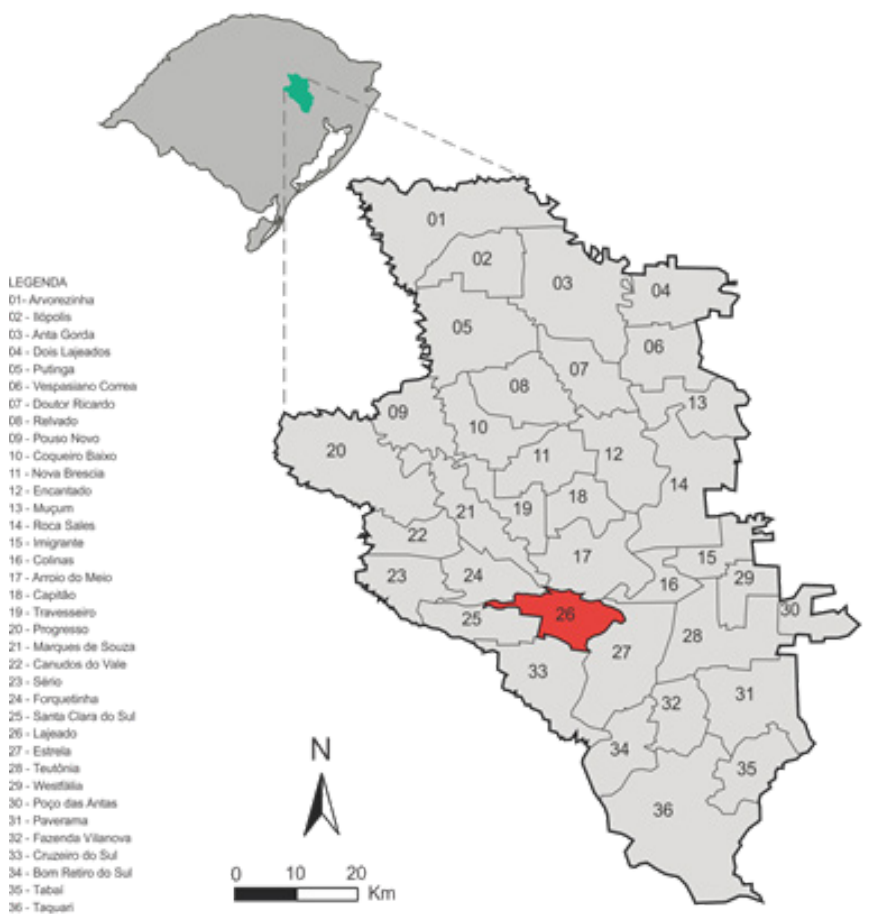

Fonte: FEE. Elaboração Bergamaschi, 2012.

A Tabela 1 demonstra a redução do número de domicilios particulares permanentes na zona rural de Lajeado de forma gradativa, tendo se acentuado entre os anos de 2000 e 2010, quando este valor sofreu redução em torno de $92,14 \%$. A redução do número de domićlíios em zona rural é inversamente proporcional ao crescimento do número de domicílios em zona urbana. Importante destacar que no ano de 2006 foi aprovado o novo Plano Diretor de Desenvolvimento Urbano de Lajeado que reduziu a zona rural municipal aumentando o número de domicílios urbanos. Essa redução também se explica pela criação, nas décadas de 1980 e 1990, de 21 novos municípios no Vale do Taquari, enquanto na década seguinte não houve novas emancipações.

Tabela 1 - Número total de domicílios na zonas urbana e rural em Lajeado nos anos de 1991, 2000 e 2010

\begin{tabular}{lccr} 
& Domicílios particulares permanentes, por situação do domicílio em Lajeado \\
Ano & Total & Urbano & Rural \\
\hline $\mathbf{1 9 9 1}$ & 17.684 & 13.558 & 4.127 \\
$\mathbf{2 0 0 0}$ & 19.703 & 18.507 & 1.196 \\
$\mathbf{2 0 1 0}$ & 24.962 & 24.868 & 94 \\
\hline
\end{tabular}

Fonte: Prefeitura Municipal de Lajeado, 2013. Elaboração de Eliza Bergamaschi.

Geografia Ensino \& Pesquisa, v. 18, n. 3 p. $07-26$, set./dez.. 2014

Os novos produtos imobiliários residenciais e as mudanças na organização espacial da cidade de Lajeado - RS
A observação e análise da Figura 2 com dados referentes à taxa de urbanização dos municípios do Vale do Taquari nos anos 1990, 2000 e 2010 permite, além de visualizar a redução do território Lajeadense, também afirmar que a taxa de urbanização tem crescido gradativamente nos últimos vinte anos. Tal aumento da população urbana é decorrente não apenas do crescimento populacional em virtude de nascimentos, mas também está relacionado a migração da população rural para o meio urbano em busca de maior remuneração, além das já mencionadas emancipações. 


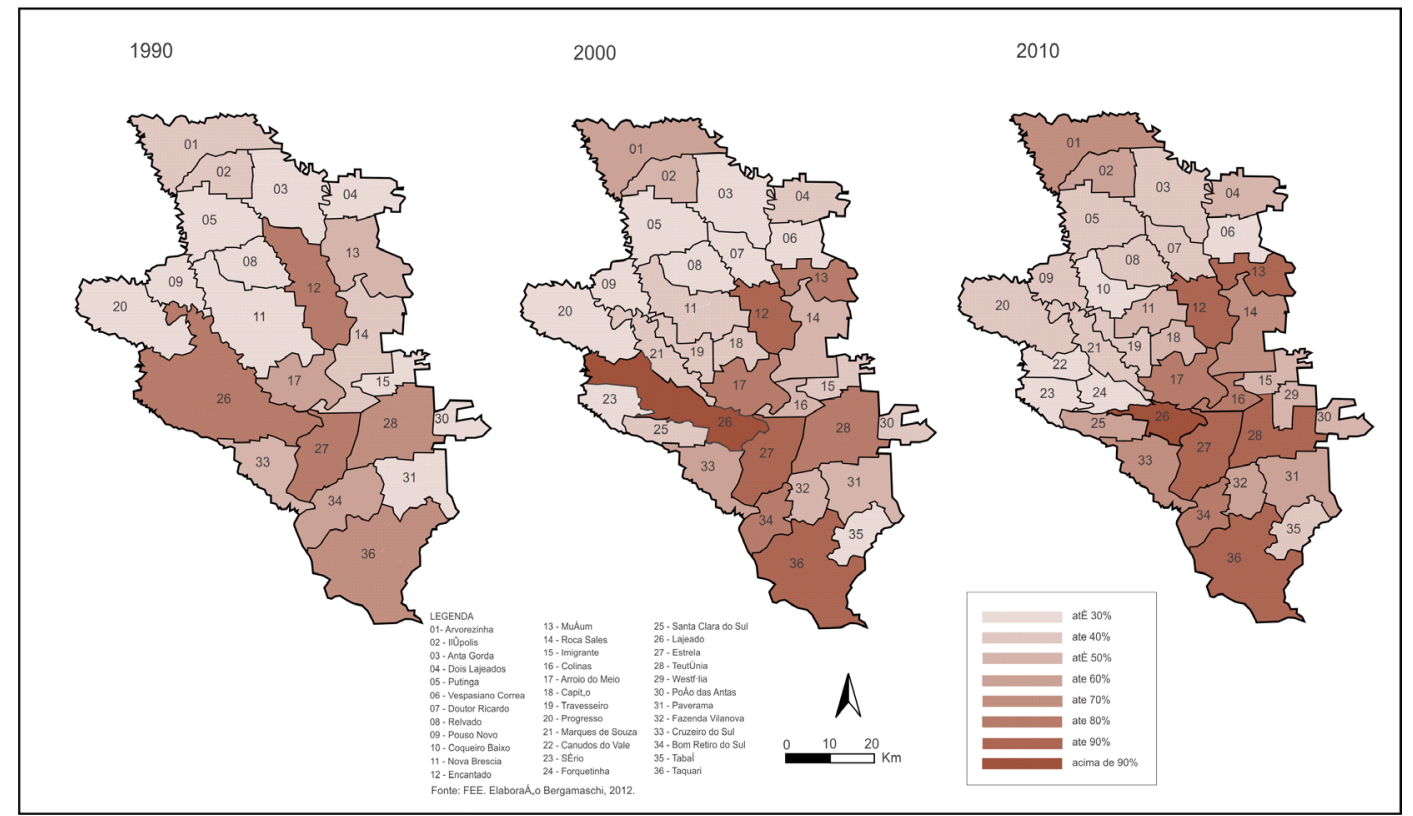

Fonte: Elaboração de Eliza Bergamaschi com base em mapa da FEE

A criação de 13 novos municípios no período de vinte anos no Vale do Taquari fez com que porções do território que se configuravam como área rural nos municípios de origem, passaram a se apresentar como parcelas urbanas destas novas municipalidades. Consequência disto, é a elevação da taxa de urbanização regional, ao mesmo tempo em que reduz o índice de população rural do Vale e principalmente de Lajeado, que sofreu uma importante redução territorial quando cedeu áreas rurais para a criação de novos municípios.

A cidade de Lajeado se destaca no cenário econômico regional. Entre os motivos desta proeminência está a localização privilegiada e a facilidade de acesso à região metropolitana e demais regiões do Estado. Tal acesso pode ser realizado através de três modais: hidroviário, ferroviário e rodoviário, principalmente através do entroncamento rodo-hidro-ferroviário na divisa com o município de Estrela.

Devido a estas facilidades no transporte de pessoas e produtos, a região criou importantes laços econômicos com os centros urbanos de Caxias do Sul e Porto Alegre configurando uma rede de relações de grande importância para o desenvolvimento do Vale do Taquari. O processo de expansão urbana destes centros regionais acabou privilegiando a região, pois a descentralização se torna cada vez mais importante em virtude da saturação da infraestrutura dos grandes centros. Diante desta realidade as margens da BR 386 se tornaram áreas atrativas à instalação de novas empresas em virtude da proximidade e da facilidade de acesso a estes outros centros (ZANCHET, 2013).

O Valor Adicionado Bruto é um índice com larga utilização e forte relação com a economia. Reflete a formação do PIB de um território, em parcelas que expressam o quanto cada setor contribuiu para a formação do Produto Interno Bruto (PIB) total.

A análise isolada de cada um dos municípios do Vale do Taquari mostra que: em 20 municípios prevalece o comércio e a prestação de serviços na composição do VAB total, em 6 municípios destaca-se a produção industrial e em 10 deles a agropecuária é a base da formação de seu VAB total.

Mesmo sendo apenas seis municípios onde prevalece a produção industrial, ela ainda ultrapassa no somatório total da região, a agropecuária que se destaca em dez municípios

Geografia Ensino \& Pesquisa, v. 18, n.3 p. 07-26, set./dez. 2014.

Bergamaschi, E.; Silveira, R. L. L. da 
regionais. A força da produção industrial regional superando a agropecuária na composição do VAB mostra que mesmo sendo em menor número, estas empresas tem grande poder de produção e contribuem em grande parte para a elevação do VAB do Vale do Taquari.

Figura 3 - Gráfico com a composição do VAB de Lajeado em 2000, 2005 e 2010.

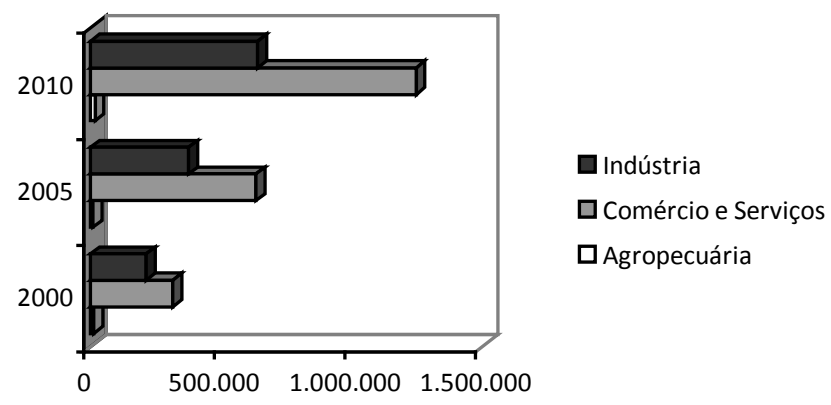

Fonte: FEEDados, 2013. Elaboração de Eliza Bergamaschi.

$\mathrm{Na}$ economia de Lajeado, há a preponderância do setor de comércio e serviços, seguido da produção industrial e com menor importância a produção agropecuária. Tal estrutura se apresenta desde o ano 2000 com essa mesma formação. Diante destes dados podemos afirmar que Lajeado é condição e reflexo das dinâmicas regionais, exercendo grande influência na região da mesma forma que sofre a influência da economia dos demais municípios do Vale do Taquari.

Em Lajeado, o direcionamento de sua economia para os ramos de comércio e prestação de serviços, juntamente com a crescente taxa de urbanização fez com o município consolidasse seu posto de polo regional. A atração de pessoas de diversas regiões do Rio Grande do Sul que buscam realizar atividades de consumo, trabalho ou estudo em Lajeado contribuiu para que o município adquirisse características urbanas cada vez mais marcantes, principalmente pela agitada atividade de sua área central. Para que isso ocorresse, Lajeado precisou se reestruturar para absorver estas atividades de forte caráter urbano, modificando relações internas e com as demais cidades que compõem a região. O mercado imobiliário é um forte ator na configuração espacial intra-urbana Lajeadense, que através do lançamento de novos produtos imobiliário para moradia ou novas tipologias residenciais contribuiu para que se criassem novas relações entre o espaço urbano e seus usuários.

\section{Reestruturação urbana em Lajeado: novos produtos imobiliários}

Geografia Ensino \& Pesquisa, v. 18, n. 3 p. $07-26$, set./dez.. 2014

Os novos produtos imobiliários residenciais e as mudanças na organização espacial da cidade de Lajeado - RS

As tipologias construtivas residenciais surgem como uma inovação lançada pelo setor imobiliário buscando obter maior lucratividade, dinamizando e movimentando o mercado de imóveis. Assim como a inovação espacial, a inovação da tipologia construtiva se configura como uma ferramenta estratégica utilizada para atrair, selecionar e suprir a demanda solvável por novos produtos imobiliários.

Segundo Koch (2008), a dinâmica do espaço urbano está relacionada ao anseio de constante diferenciação dos estoques residenciais. Os segmentos sociais com rendas superiores consomem tipologias com maior exclusividade física, maiores áreas privativas e mais equipamentos de lazer e serviços disponíveis. 
Num primeiro momento, as classes com maior renda demandam novas edificações com características de exclusividade e diferenciação das demais. Estas características podem se basear numa localização diferenciada, com acessos facilitados, atrativos naturais e uma vizinhança com as mesmas características sócio econômicas. Da mesma forma a inovação tipológica atrai estes consumidores que buscam por edificações diferenciadas em meio a uma malha urbana consolidada, ressaltando sua posição econômica e social.

Após o lançamento de uma nova tipologia, esta passa a ser repetida e copiada pelas classes com rendas inferiores que se apropriam desta inovação e passam a imitá-la até chegar numa padronização construtiva e tipológica.

A repetição de um padrão tem duas consequências no espaço urbano em diferentes escalas: uma é a renovação das edificações em uma localização existente, que vai atualizar a estética do bairro com construções mais modernas e consequentemente aumentar/manter o valor imobiliário daquela localização e do seu entorno. A segunda consequência é o surgimento de uma homogeneidade construtiva que pode ser visualizada em toda a malha urbana com a reprodução de um padrão como podemos observar na Figura 4.

Figura 4 - Padronização de faces de quadra com a repetição da tipologia construtiva em Lajeado
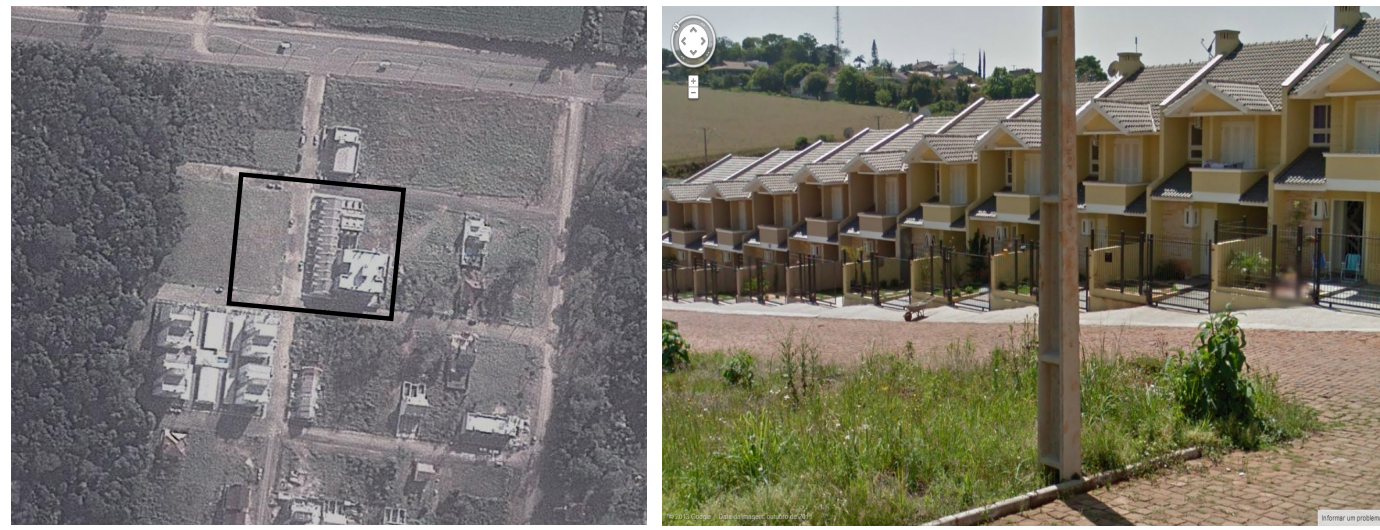

Fonte: Google Maps e Google Street View.

Na cidade de Lajeado, a tipologia dos sobrados em fita pode ser encontrada em 363 condomínios na malha urbana. De diferentes padrões e tipologias construtivas, este tipo de moradia está presente em 19 dos 26 bairros da cidade, em diferentes proporções. Independente da quantidade que se encontra em cada bairro, a padronização do meio urbano gerado pela repetição desta tipologia cria grandes planos padronizados e homogêneos, chegando a apresentar faces inteiras de quadra com a tipologia dos condomínios de sobrados.

Após o largo emprego de uma mesma tipologia a padronização e o seguinte esgotamento da localização, faz com que as classes superiores demandem novas formas construtivas e localizações exclusivas iniciando novamente este ciclo. O mercado cumpre seu papel de movimentação imobiliária e lança novas tipologias que serão repetidas até chegar a padronização e esgotamento de novas parcelas urbanas. Viabiliza-se assim, de modo recorrente, as condições para se garantir a continuidade da reprodução do capital através da produção e comercialização do ambiente construído. (HARVEY, 2001).

Em Lajeado, identificamos 5 tipologias construtivas para os condomínios residenciais. Três destas tipologias correspondem a diferentes padrões construtivos para o mesmo produto: o sobrado. Este se apresenta na malha urbana com diferentes modelos de implantação no lote e de utilização dos espaços coletivos, porém são compostos por casas em fita, na maioria de dois pavimentos, e nas quais se comercializa a edificação pronta. As outras duas tipologias encontradas em Lajeado, se relacionam à propriedade de lotes individualizados.

Geografia Ensino \& Pesquisa, v. 18, n. 3 p. $07-26$, set./dez. 2014.

Bergamaschi, E.; Silveira, R. L. L. da 
Figura 5 - Face de quadra com 3 condomínios de sobrados em Lajeado
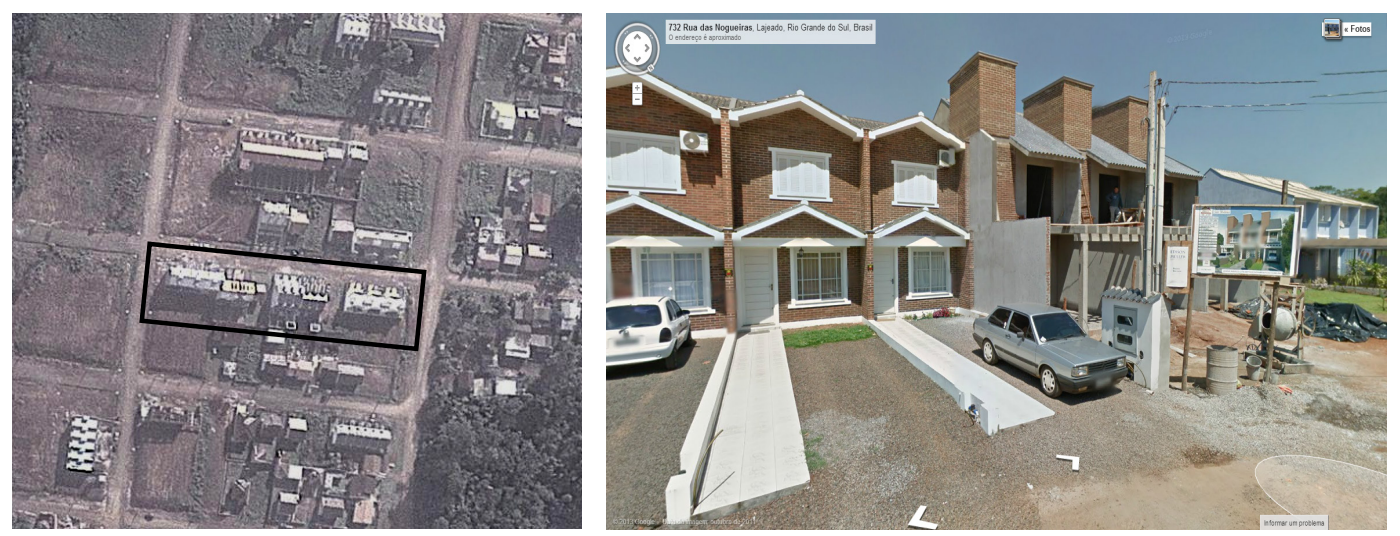

Fonte: Google Maps e Google Street View.

A metodologia empregada para a localização e categorização destes empreendimentos se baseou em imagens disponíveis pelas ferramentas Google Maps e Google Street View. Inicialmente realizou-se a identificação e localização das construções em condomínios nas imagens (aéreas) de satélite de junho de 2012. A forma construtiva de seus telhados, assim como o fato de serem casas geminadas em fita formando grandes blocos maciços na malha urbana, facilitou a identificação e a localização dos condomínios.

Após a demarcação em mapa de todas as edificações com estas características foi feita a verificação no Google Street View das fachadas e faces de quadra onde estas moradias estão localizadas. Em função da diferença na data da obtenção das imagens (Google Maps de junho de 2012 e Google Street View de junho de 2011), algumas edificações encontradas pela imagem de satélite não existiam na data da obtenção das imagens do Street View e apareciam como lotes vazios. Outras parcelas urbanas ainda não haviam sido mapeadas pelo Street View, mas era possível afirmar pela imagem de satélite a existência desta tipologia construtiva. Desta forma, partimos para a confirmação in loco dos empreendimentos em zonas não mapeadas e daqueles que foram construídos no intervalo de tempo entre os dois levantamentos realizados pelo Google. A verificação in loco nos proporcionou a confirmação da existência de mais 77 empreendimentos assim como o levantamento fotográfico das fachadas destes condomínios.

Além destes condomínios que puderam ser identificados, localizados e analisados através da utilização destas ferramentas, dados obtidos junto à Prefeitura Municipal de Lajeado informaram a entrada de projetos de construção de mais 113 condomínios de casas assobradas no período de agosto de 2012 até outubro de 2013, totalizando 364 condomínios.

Estes 113 condomínios edificados ou em fase de construção não puderam ser classificados nem localizados no mapa de Lajeado, pois os dados obtidos juntos a este órgão público não foram suficientes para sua localização e classificação. Desta forma, utilizaremos para análise apenas os 251 condomínios que puderam ser localizados e classificados. Apesar disto, a importância de 113 novos condomínios no período de 14 meses demonstra

Geografia Ensino \& Pesquisa, v. 18, n. 3 p. $07-26$, set./dez.. 2014

Os novos produtos imobiliários residenciais e as mudanças na organização espacial da cidade de Lajeado - RS que esta tipologia ainda continua sendo empregada em larga escala na malha urbana. Relacionando com as informações apresentadas anteriormente podemos afirmar que: até junho de 2011 havia 174 condomínios em Lajeado. De junho de 2011 a junho de 2012, foram construídos 77 condomínios. De agosto de 2012 a outubro de 2013 foram encaminhados projetos para construção de mais 113 condomínios totalizando 363 condomínios edificados ou em fase de construção na malha urbana Lajeadense até outubro de 2013. 
Tabela 2 - Evolução da quantidade de condomínios em Lajeado.

\begin{tabular}{lcc} 
Período & $\begin{array}{c}\text { Condomínios construídos ou } \\
\text { encaminhados para } \\
\text { aprovação }\end{array}$ & Total de condomínios \\
\hline Até junho de 2011 & 174 & 174 \\
\hline Junho de 2011 a junho de 2012 & 77 & 251 \\
Novembro de $\mathbf{2 0 1 2}$ a outubro de 2013 & 113 & 363 \\
\hline
\end{tabular}

Fonte: Trabalho de campo, PML ${ }^{2}$. Elaborado por Eliza Bergamaschi.

Dando continuidade à análise tipológica dos condomínios em Lajeado, estes empreendimentos foram divididos em cinco categorias segundo características em comum. Para a categorização das tipologias arquitetônicas foi utilizado o critério de interação entre os moradores, uma vez que a presença de uma forma condominial já pressupõe uma vida em sociedade, onde todos os proprietários dividem a posse das parcelas de uso comum do condomínio.

Os diferentes níveis de sociabilidade e a presença de equipamentos de uso comum nos possibilitaram a divisão em cinco categorias ${ }^{3}$ :

A) Condomínio sem área comum: residências geminadas ou assobradadas com acessos independentes, todas voltadas para o passeio público, sem áreas de uso comum dos moradores;

Figura 6-Condomínio tipo A

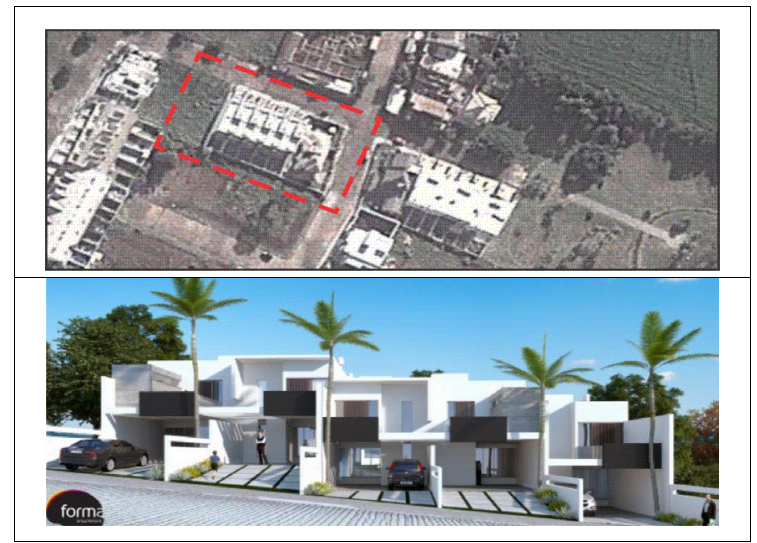

Fonte: Imagens Google Maps e Google Street View.

B) Condomínio com circulação interna de uso comum: composto por unidades residenciais cujo acesso se realiza por uma via de trânsito interna ao condomínio;

Figura 7 - Condomínio tipo B

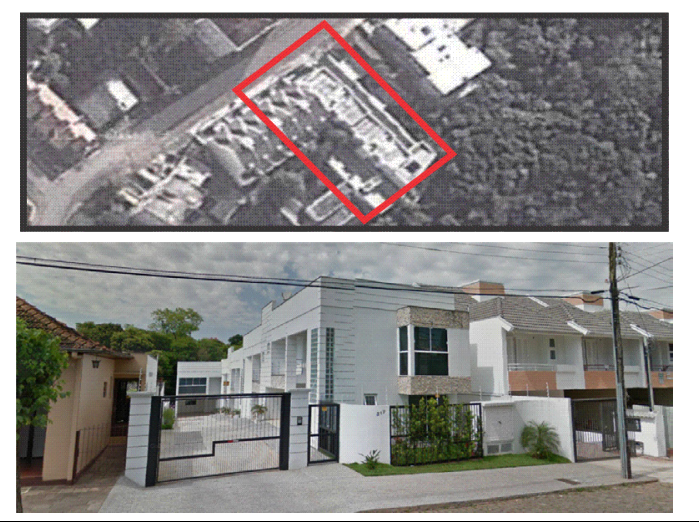

${ }^{2}$ PML - Prefeitura Municipal de Lajeado.

${ }^{3}$ Para esta categorização foram utilizadas as denominações segundo nossos critérios de entendimento dos processos de criação destes condomínios, independentemente da forma como foram encaminhados e aprovados pelo poder público municipal.

Geografia Ensino \& Pesquisa, v. 18, n. 3 p. $07-26$, set./dez. 2014. 
C) Condomínio com área de convívio em comum: nesta tipologia, além da via de trânsito de veículos interna ao condomínio, o empreendimento conta com área de uso comum dos moradores como salão de festas, piscina ou playground;

Figura 8-Condomínio tipo C.
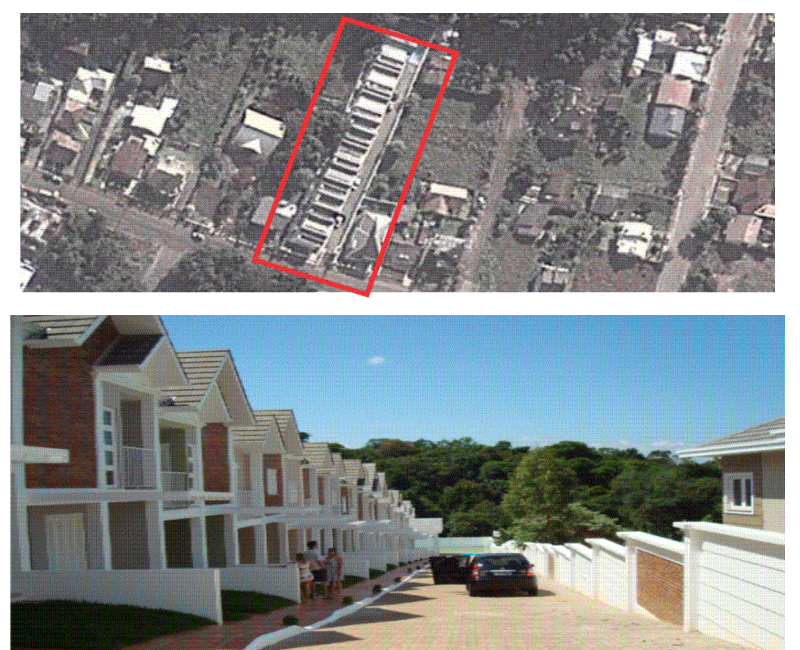

Fonte: Imagens Google Maps, 2013, e Google Street View, 2013.

D) Condomínios urbanísticos (de lotes): tratam-se das residências em espaços delimitados por muros ou grades, com acesso restrito e controlado, sendo cada residência situada em lotes individualizados;

Figura 9-Condomínio tipo D

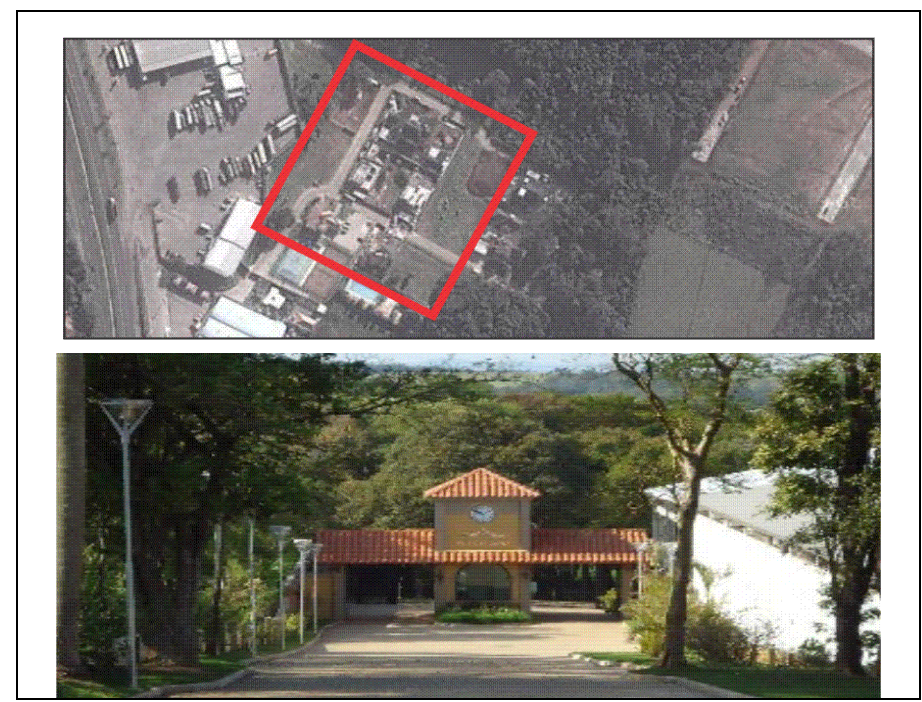

Fonte: Imagens Google Maps, 2013, e Google Street View, 2013.

E) Loteamentos fechados: são loteamentos que foram aprovados como abertos e que posteriormente

Geografia Ensino \& Pesquisa, v. 18, n. 3 p. $07-26$, set./dez.. 2014

Os novos produtos imobiliários residenciais e as mudanças na organização espacial da cidade de estabeleceram acesso restrito e controlado, reproduzindo a tipologia dos condomínios urbanísticos.

Através do levantamento quantitativo e da classificação qualitativa dos empreendimentos encontramos 241 unidades do tipo A, duas unidades do tipo $\mathrm{B}$, cinco unidades do tipo $\mathrm{C}$, duas unidades do tipo $\mathrm{D}$ e uma unidade do tipo $\mathrm{E}$, totalizando 251 empreendimentos em forma de condomínios. 


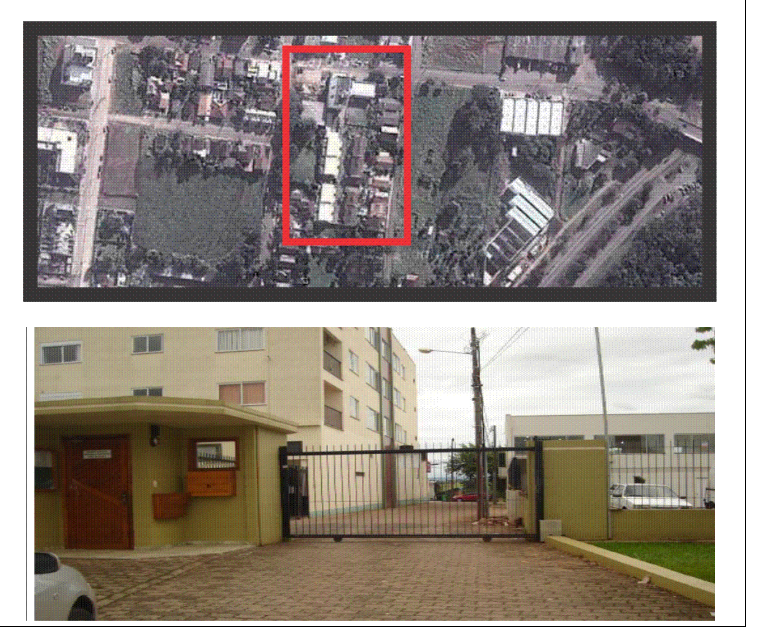

Fonte: Imagens Google Maps, 2013, e Google Street View, 2013.

Tabela 3 - Condomínios identificados e analisados em Lajeado por tipologia

\begin{tabular}{cc}
\hline Tipo & $\begin{array}{c}\text { Número de condomínios } \\
\text { identificados }\end{array}$ \\
\hline A & 241 \\
B & 02 \\
C & 05 \\
D & 02 \\
E & 01 \\
Total & $\mathbf{2 5 1}$ \\
\hline
\end{tabular}

Fonte: Levantamento de campo. Elaboração de Eliza Bergamaschi.

A dinâmica de localização destes empreendimentos está condicionada à estrutura urbana do município. A malha urbana de Lajeado é cortada no sentido norte-sul pela BR 386 e no sentido leste oeste pela RS 130 o que a divide em quaro quadrantes. O bairro Centro, núcleo urbano inicial se localiza no quadrante sudeste. De forma contínua ao bairro centro e no sentido oeste existe hoje o bairro Moinhos que é delimitado pela RS 130, encerrando este quadrante. Em continuidade com o bairro Moinhos, estão os bairros Montanha e Moinhos D'água formando uma mancha contínua ao bairro Centro.

Já no quadrante nordeste se encontra a UNIVATES, que atrai estudantes e profissionais de toda região. A facilidade de acesso a UNIVATES através da RS 130, a Avenida Senador Alberto Pasqualini (radial), a Avenida Amazonas (perimetral) e a Avenida Avelino Talini (via de ligação) contribuíram para que a UNIVATES e seu entorno se desenvolvessem urbanisticamente nos últimos anos. Tais vias possuem maior hierarquia na rede viária, possibilitando deslocamentos rápidos e facilitados pela pavimentação asfáltica, o que contribui para uma melhor circulação naquela região.

O bairro Universitário se desenvolveu no entorno da UNIVATES. A ação da construtora Zagonel naquele quadrante e no ano de 1998 com a instalação do Loteamento Verdes Vales que contava com 337 lotes, estimulou a urbanização e a ocupação do bairro. A importância da criação deste loteamento é tal que muitas pessoas ainda reconhecem o bairro como Verdes Vales e não como Bairro Universitário.

São nos bairros Montanha, Moinhos, Moinhos D’água e Universitário que se concentram a maior parte dos condomínios em Lajeado: 138 condomínios, o que corresponde a 54,98\% do total. Destes condomínios, 132 são do tipo A, um é tipo B, 04 tipo C e mais um é tipo E.

Geografia Ensino \& Pesquisa, v. 18, n.3 p. $07-26$, set./dez. 2014.

Bergamaschi, E.; Silveira, R. L. L. da 


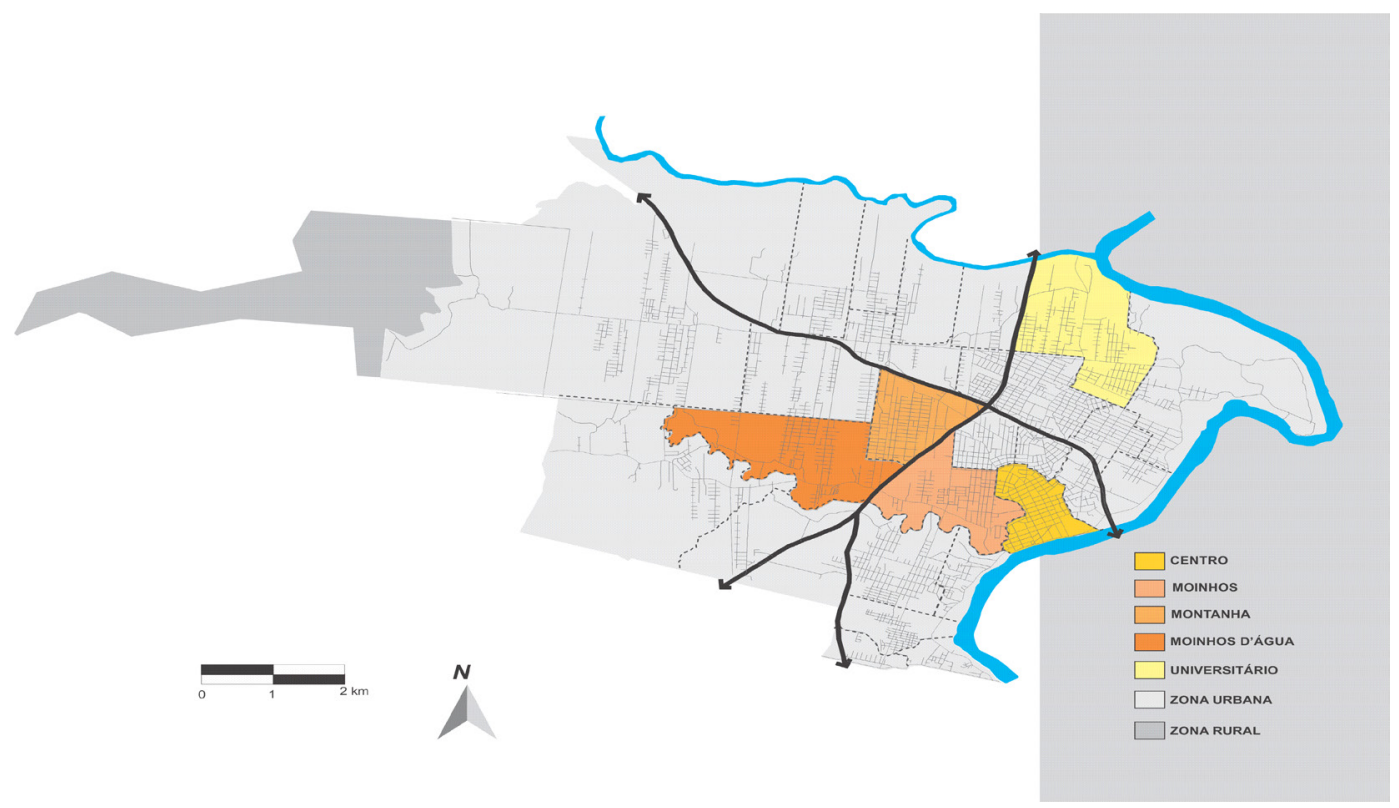

Fonte: Elaboração de Eliza Bergamaschi sob base cartográfica da Prefeitura Municipal.

Os condomínios tipo D recentemente inseridos na malha urbana, não estão localizados em nenhum destes bairros onde a malha urbana já está consolidada e onde predominam as demais tipologias. A estratégia de exclusividade de localização almejada por estes empreendimentos que passam a se configurar como empreendimentos com inovação de localização e de tipologia direciona-os para as classes mais altas da população Lajeadense.

Desta forma podemos concluir que a distribuição dos condomínios em Lajeado tem forte relação de localização, dependência locacional e de proximidade, pois estão localizados no entorno de pontos de forte atração de pessoas: o bairro Centro e a UNIVATES, assim como se configuram como locais de fácil acesso através de vias de trânsito rápido.

Tabela 4 - Localização dos condomínios segundo as Unidades Territoriais.

Geografia Ensino \& Pesquisa, v. 18, n. 3 p. $07-26$, set./dez.. 2014

Os novos produtos imobiliários residenciais e as mudanças na organização espacial da cidade de

Lajeado - RS \begin{tabular}{llllll} 
Tipo A Tipo B & Tipo c & Tipo D & Tipo E Somatório \\
\hline
\end{tabular}

\begin{tabular}{|c|c|c|c|c|c|c|}
\hline UT Residencial & 89 & 02 & 04 & - & - & 93 \\
\hline UT Residencial Unifamiliar & 28 & - & - & - & - & 28 \\
\hline Ut Residencial Popular & 15 & - & - & - & - & 15 \\
\hline UT Residencial Especial & 08 & - & - & 01 & - & 09 \\
\hline UT Mista & 83 & - & 01 & 01 & - & 85 \\
\hline UT Comércio e Serviço & 05 & - & - & - & 01 & 06 \\
\hline $\begin{array}{l}\text { Polo de Comércio e } \\
\text { Serviço }\end{array}$ & 02 & - & - & - & - & 02 \\
\hline
\end{tabular}

$\begin{array}{lccccc}\text { Corredor de Comércio e } & - & - & - & - & - \\ \text { Serviço } & & & -11 \\ \text { UT Especial } & 11 & - & - & - & -\end{array}$

\begin{tabular}{|c|c|c|c|c|c|c|}
\hline UT Rural & - & - & - & - & - & - \\
\hline UT Industrial & - & - & - & - & - & - \\
\hline Somatório & 241 & 02 & 05 & 02 & 01 & 251 \\
\hline
\end{tabular}

Fonte: Pesquisa de campo. Elaboração de Eliza Bergamaschi. 
O Plano Diretor de Desenvolvimento Integrado de Lajeado vigente é do ano de 2006. Esta legislação divide o município em zona urbana e zona rural. A zona urbana sofre mais parcelamentos em Unidades Territoriais (UT), as quais tem o caráter de regulamentar os usos e índices construtivos permitidos na malha urbana. Além das 9 UTs, ainda há a classificação como Polo de Comércio e Serviço (PCS) e Corredor de Comércio e Serviço (CCS), totalizando 11 subcategorias para a zona urbana. Estas categorias não se apresentam de forma contínua formando grandes áreas uniformes, mas sim em manchas de diferentes proporções dispersas na malha urbana, como podemos observar na Figura12.

Figura 12 - Localização dos condomínios nas diferentes zonas de uso de Lajeado

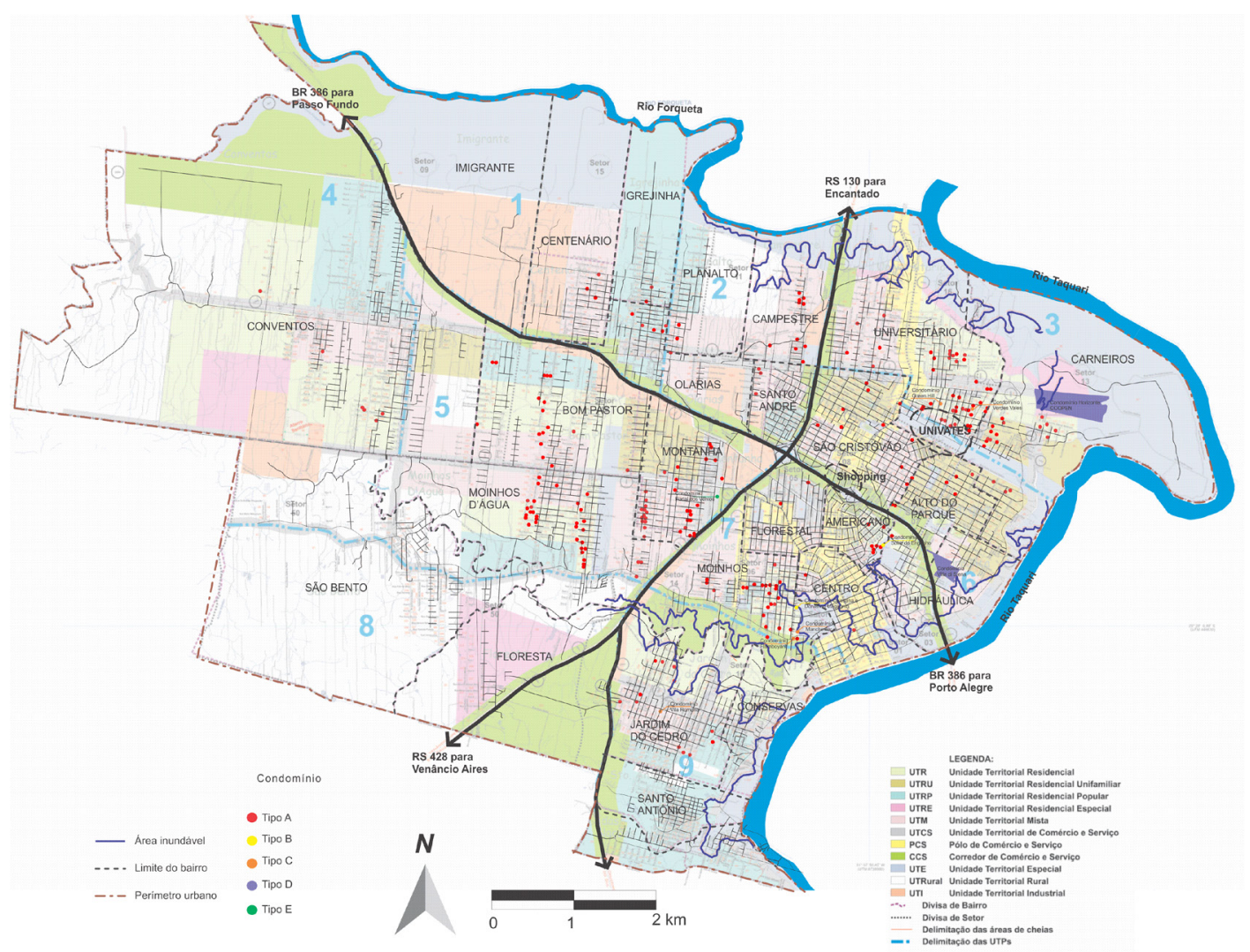

Fonte: Elaboração de Eliza Bergamaschi sob base cartográfica da Prefeitura Municipal.

Os condomínios se localizam em 7 UTs diferentes estando presentes também nos PCS e CCS. Das 7 UTs, 4 delas são de uso exclusivo residencial (unidade territorial residencial, residencial popular, residencial unifamiliar e residencial especial). As demais UTs são mista, especial e de comércio e serviço.

Na atual legislação urbanística de Lajeado, aprovada em 2006, a construção de sobrados sofreu restrição de localização. Criou-se a denominação de Unidade Territorial Residencial Unifamiliar na qual não poderiam ser construídas casas em condomínio. O poder público municipal, visando facilitar o entendimento das prerrogativas legislativas aplicadas a estas construções, utiliza a expressão "prédio deitado" para caracterizar os sobrados que são tratados como edificações multifamiliares. Existem na malha urbana de Lajeado apenas seis áreas onde esta especificação se aplica.

Um fato importante de ser ressaltado é que parcela da população de Lajeado residente na divisa dos bairros Alto do Parque e Carneiros e próximo ao Condomínio COOPEN (tipo D) entrou com um pedido junto ao Poder Público Municipal solicitando a mudança de classificação daquela área, que passou a ser Unidade Territorial Residencial Unifamiliar, onde

Geografia Ensino \& Pesquisa, v. 18, n.3 p. $07-26$, set./dez. 2014.

Bergamaschi, E.; Silveira, R. L. L. da 
não são permitidos condomínios de casas assobradadas. A intervenção da população com a elaboração de um abaixo assinado solicitando esta mudança de interesse exclusivamente particular, foi atendida. Os proprietários que organizaram tal movimento se sentiram protegidos pela legislação. Em contrapartida, os investidores que haviam adquirido lotes com o objetivo de edificar construções assobradadas, principalmente pela região ser bastante valorizada pela proximidade da UNIVATES se sentiram lesados pela restrição de construção.

Ainda com relação à localização dos condomínios nas diferentes UTs, verificamos a presença de 28 destes empreendimentos na Unidade Territorial Residencial Unifamiliar. Segundo a Prefeitura Municipal, estes condomínios foram construídos antes da legislação de 2006.

Relacionando as tipologias e a localização da malha urbana, não podemos afirmar que existe um padrão de localização de determinada tipologia numa UT específica, mas sim a predominância dos condomínios tipo B, C, D e E se localizarem na UT residencial e na UT mista. A localizações das demais unidades destas tipologias não seguem um padrão de localização, estando localizadas em 6 setores diferentes: UT residencial unifamiliar, residencial popular, especial, comércio e serviços, corredor de comércio e serviços e polo de comércio e serviço.

Já a localização dos condomínios tipo A na malha urbana se distribui em quase todas as divisões territoriais exceto nas UT industrial e UT rural. É visível a predominância da tipologia nas UTs residencial, mista e residencial popular, justamente aquelas onde predomina a existência dos condomínios em geral, independente de sua tipologia.

Somando a quantidade de condomínios tipo A localizados nestas três UTs (residencial, mista e residencial popular) obtemos o somatório de 200 empreendimentos condominiais. Este valor corresponde a 79,6\% do total dos condomínios de Lajeado, independente de sua tipologia.

Tabela 5-A presença dos condomínios e o rendimento nominal médio mensal por bairro de Lajeado

\begin{tabular}{|c|c|c|c|c|c|c|}
\hline Bairro & Tipo A & Tipo B & Tipo C & Tipo D & Tipo E & $\begin{array}{r}\text { Renda média } \\
\text { em } 2010\end{array}$ \\
\hline Alto do Parque & 06 & - & - & - & - & $\mathrm{R} \$ 6.097,48$ \\
\hline Americano & 07 & 01 & - & - & - & $R \$ 4.295,48$ \\
\hline Bom Pastor & 17 & - & - & - & - & $\mathrm{R} \$ 2.159,95$ \\
\hline Campestre & 10 & - & - & - & - & $\mathrm{R} \$ 2.118,24$ \\
\hline Carneiros & 18 & - & - & 01 & - & $\mathrm{R} \$ 3.823,78$ \\
\hline Centenário & 03 & - & - & - & - & $\mathrm{R} \$ 2.049,72$ \\
\hline Centro & 02 & - & - & - & - & $\mathrm{R} \$ 3.275,40$ \\
\hline Conservas & - & - & - & - & - & $\mathrm{R} \$ 1.485,14$ \\
\hline Conventos & 06 & - & - & - & - & $\mathrm{R} \$ 1.857,71$ \\
\hline Floresta & - & - & - & - & & $\mathrm{R} \$ 2.273,35$ \\
\hline Florestal & 02 & - & - & - & - & $\mathrm{R} \$ 3.233,37$ \\
\hline Hidráulica & 01 & - & - & 01 & - & $\mathrm{R} \$ 3.898,95$ \\
\hline Igrejinha & 02 & & & & & $\mathrm{R} \$ 1.564,65$ \\
\hline Imigrante & - & - & - & - & - & $\mathrm{R} \$ 1.781,81$ \\
\hline Jardim do Cedro & 12 & - & 01 & - & - & $\mathrm{R} \$ 1.863,18$ \\
\hline Moinhos & 24 & 01 & 02 & - & - & $\mathrm{R} \$ 3.703,81$ \\
\hline Moinhos D’água & 33 & - & - & - & - & $\mathrm{R} \$ 2.083,70$ \\
\hline Montanha & 33 & - & - & - & 01 & $\mathrm{R} \$ 2.740,10$ \\
\hline Morro 25 & - & - & - & - & - & $\mathrm{R} \$ 1.455,29$ \\
\hline Nações & - & - & - & - & - & $\mathrm{R} \$ 1.507,49$ \\
\hline Olarias & 05 & - & - & - & - & $\mathrm{R} \$ 1.975,13$ \\
\hline Planalto & 03 & - & - & - & - & $\mathrm{R} \$ 1.554,93$ \\
\hline Santo André & 03 & - & - & - & - & $\mathrm{R} \$ 1.749,69$ \\
\hline Santo Antônio & - & - & - & - & - & $\mathrm{R} \$ 1.299,87$ \\
\hline São Bento & - & - & - & - & - & $\mathrm{R} \$ 1.897,12$ \\
\hline São Cristóvão & 11 & - & - & - & - & $\mathrm{R} \$ 3.210,09$ \\
\hline Universitário & 43 & - & 02 & - & - & $\mathrm{R} \$ 2.729,07$ \\
\hline Renda média municipal & & & & & & $\mathrm{R} \$ 2.506,83$ \\
\hline
\end{tabular}

Os novos produtos imobiliários 
A localização dos condomínios e a renda dos moradores de cada bairro expõe uma importante característica destes empreendimentos: não há um padrão de público específico para o qual são voltados. Dispersos em vários bairros da malha urbana que apresentam diferentes rendas populacionais, os condomínios de Lajeado possuem distinção de padrão construtivo direcionando os produtos para um público específico que pode ter acesso financeiro a aquele imóvel, não havendo uma padronização.

Figura 13 - Renda e a presença dos condomínios em Lajeado

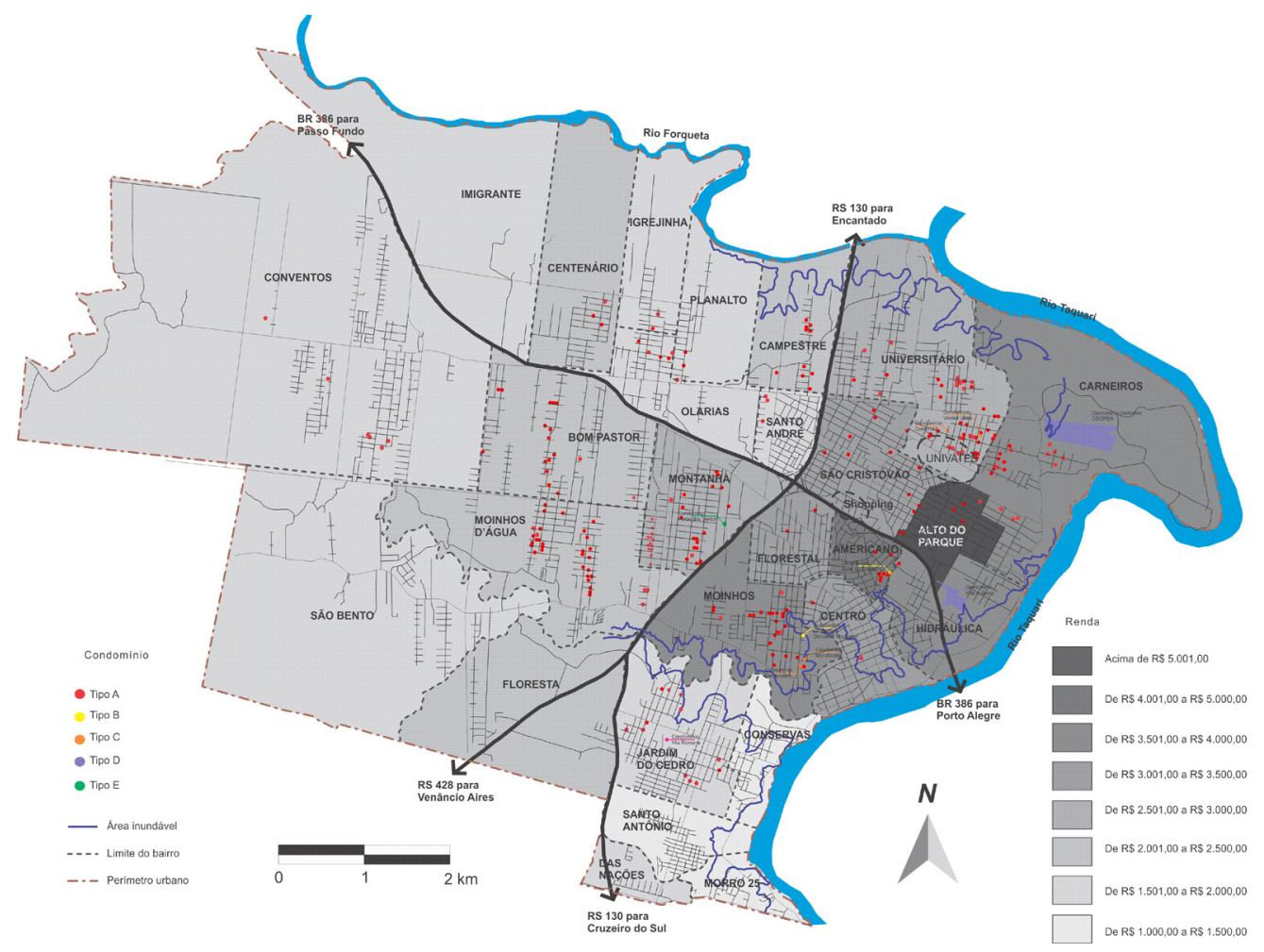

Fonte: Elaboração Eliza Bergamaschi sob base cartográfica da Prefeitura Municipal 2013.

A localização dos condomínios nos diferentes bairros de Lajeado nos permite observar que eles se concentram em duas regiões: na mancha contínua ao bairro Centro (quadrantes sudeste e sudoeste) e no bairro Universitário que fica no quadrante nordeste. A relação ente a renda dos habitantes dos bairros de Lajeado e a presença dos condomínios nestes bairros demonstra a dinâmica de implantação destes empreendimentos na malha urbana.

O que se pode verificar em outras cidades, e principalmente nas metrópoles, é a repetição da tipologia de casas em sobrados voltadas para a população de menor renda. Em Lajeado, isto não acontece. Os bairros com as menores rendas não possuem construções assobradas ou elas são muito raras. Mesmo havendo 15 condomínios localizados na Unidade Territorial Residencial Popular dos bairros Igrejinha, Bom Pastor, Olarias e Jardim do Cedro, a renda média destes bairros não se configura entre as menores rendas do município.

\section{Conclusão}

Geografia Ensino \& Pesquisa, v. 18, n.3 p. 07-26, set./dez. 2014.

A cidade de Lajeado se insere num contexto onde as cidades médias passam a ganhar cada vez mais destaque como polos regionais e de atração de investimentos e população, intensifican- 
do as relações entre o território municipal e a região onde se insere. Como importante ator no processo de urbanização está o mercado imobiliário que com suas estratégias modifica e constrói a estética e a configuração espacial da cidade. Desta forma se torna impossível dissociar o processo de estruturação urbana das estratégias e formas de atuação do mercado imobiliário assim como dos métodos adotados pelo Poder Publico Municipal, principais agentes identificados em Lajeado.

A construção de moradias em condomínio é uma estratégia de mercado utilizada em inúmeras cidades contemporâneas, não permitindo que Lajeado fique fora deste contexto. No entanto, em Lajeado esse processo apresenta características muito marcantes, específicas deste município, com a ampla construção de casas assobradadas.

Neste sentido, Lajeado se diferencia das demais cidades médias do interior do Rio Grande do Sul, uma vez que não tendo atingido o mesmo patamar de desenvolvimento sua configuração intra-urbana possui características específicas. Acreditamos que, as atuais características urbanísticas de Lajeado já foram as características vigentes de outras cidades médias em outros momentos de seu desenvolvimento urbano. Por este motivo, acreditamos que a escassa presença de condomínios e loteamentos fechados em Lajeado seja apenas temporária, uma vez que seu padrão de desenvolvimento, no momento, ainda não comporte a presença de mais empreendimentos deste tipo.

A ampla presença de condomínios de casas assobradadas com diferentes padrões construtivos se apresenta como uma alternativa econômica diante da escassez de lotes disponíveis nas áreas centrais da cidade aliado aos altos valores exigidos pelo mercado imobiliário para a aquisição destas parcelas do solo urbano. Desta forma, também o reduzido número de empreendimentos em forma de condomínios e loteamentos fechados se apresenta como uma alternativa restrita à população de alta renda.

Além da relação entre o preço da terra e o acesso a estes produtos imobiliários, a produção de condomínios de sobrados se relaciona com a falsa impressão de posse de uma parcela de terras, onde o proprietário possa realizar melhorias e ampliações em sua unidade residencial. Esta prática é recorrente entre os proprietários de casas nestes tipos de condomínios, no entanto se apresenta de forma ilegal perante a legislação existente. O fato de haver uma legislação precária e ineficiente associado ao fato da carência de fiscalização pelo Poder Público Municipal estimula a comercialização destes empreendimentos e a realização destas modificações das propriedades.

Junto a estes fatores associa-se a posse de uma casa, onde se materializa a existência de um núcleo familiar, a liberdade e a privacidade das edificações em condomínios horizontais faz com que o mercado deste tipo de empreendimento se apresente de forma bastante aquecida por muitos anos. A preferência por adquirir um sobrado a um apartamento é comum entre os moradores de Lajeado, que encontram nesta tipologia construtiva os símbolos de status, caracterizado pela busca por segurança, isolamento, homogeneidade, a presença de equipamentos de lazer e a prestação de serviços identificados por Caldeira (2003), nos condomínios da cidade de São Paulo.

Desta forma, os condomínios horizontais de casas assobradadas se apresentam como uma das mais importantes características da reestruturação urbana que Lajeado apresenta em seus últimos vinte anos de crescimento e desenvolvimento. Através desta dinâmica urbana, podemos afirmar que Lajedo se insere nas dinâmicas de desenvolvimento urbano e de reprodução do capital imobiliário em escala mundial onde os novos produtos imobiliários se apresentam como uma nova forma de apropriação do espaço urbano e de moradia, assim como uma forma de obtenção de lucro em escala.

Acreditamos também que, nos próximos anos, o desenvolvimento urbano aliado à escassez de amplas áreas de terras a leste da rodovia RS 130, contribuam para a realização mais intensa em Lajeado de novos produtos imobiliários como os já existentes em cidades de maior porte: novos empreendimentos em forma de condomínios e loteamentos fechados nas periferias urbanas. Os dois condomínios urbanísticos existentes em Lajeado estão localizados em parcelas 
diferentes da malha urbana porém com fortes relações de proximidade com o centro tradicional. Uma vez que a malha urbana já se encontra saturada na faixa entre a RS 130 e o Rio Taquari, os novos eixos de crescimento e as novas urbanizações voltaram seu crescimento para a porção oeste da RS130, cada vez mais distante da área central do município.

A falta de uma legislação municipal eficiente que regule e oriente esse processo é uma das grandes preocupações do Poder Público Municipal, que atualmente precisa estudar cada caso com características específicas em separado, criando para estas novas tipologias regras que serão seguidas para os próximos empreendimentos. Devido a esta ineficiência legislativa encontramos alguns casos contraditórios, como no Loteamento Fechado Portal dos Ventos, onde todas as unidades se constituem de lotes individualizados porém sem possuir testada para uma via pública como determinado pela Lei 6766, de 1979.

Os agentes promotores deste tipo de edificação são em grande parte moradores e empreendedores de Lajeado, que viram neste nicho de mercado uma estratégia de reprodução de seu capital. Além de empresas constituídas e tradicionais há muitos empreendedores individuais que adquirem um lote e constroem um condomínio de casas assobradadas para vendê-las e assim obter lucro. Além da construção a maioria destes agentes também realiza a comercialização das unidades residenciais como uma forma de apropriação do lucro das imobiliárias que também realizam estes negócios.

Estes importantes agentes estruturadores do espaço urbano de Lajeado atuam se aproveitando da falta de uma legislação mais eficiente e da disponibilidade de recursos gerada pelo Programa Minha Casa Minha Vida de financiamento habitacional para deixar sua marca no espaço urbano de Lajeado, que se encontra hoje caracterizado pela ampla reprodução dos condomínios de sobrados.

A facilidade de acesso às casas assobradadas através do Programa Minha Casa Minha Vida de financiamento habitacional, estimula ainda mais este mercado de casas em condomínio. Com diferentes padrões construtivos e de localização, além de distintas faixas de valor de mercado, os sobrados se apresentam em Lajeado como uma forma democrática de moradia, pois atendem a todas as classes sociais.

Diante do exposto, podemos afirmar que mesmo Lajeado sendo uma cidade média, que se destaca como polo regional de atração de investimentos e população, o município segue as mesmas dinâmicas encontradas no passado de outras cidades de maior porte, fazendo com que seu futuro seja promissor de grandes investimentos principalmente àqueles relacionados ao mercado imobiliário e as configurações urbanas e espaciais.

\section{Referências}

BAENINGER, Rosana. Reestruturação urbana: algumas considerações sobre o debate atual. 1998. Disponível em: <https://www.cprepmass.com.br/documentos/reestruturacaourbanaealgumasconsideracaes1647.pdf >. Acesso em: 14 out. 2012.

BRASIL. Lei no 6.766, de 19 de dezembro de 1979 - Presidência da República. Disponível em: <www. planalto.gov.br/ccivil_03/leis/14591.htm>. Acesso em: out. 2013.

CALDEIRA, Teresa Pires do Rio. Cidade de muros: crime, segregação e cidadania em São Paulo. 2. ed. São Paulo: Edusp, 2003.

CARLOS, Ana Fani. A cidade. 6. ed. São Paulo: Contexto, 2001.

Geografia Ensino \& Pesquisa, v. 18, n.3 p. $07-26$, set./dez. 2014.

CASTELLS, Manuel. Capital multinacional, estados nacionales y comuniade locales. 2. ed. México: Siglo Veintiuno, 1987.

Bergamaschi, E.; Silveira, R. L. L. da

CORRÊA, Roberto Lobato. Construindo o conceito de cidade média. In: SPOSITO, M. E. B. (Org). 
Cidades Médias: espaços em transição. $1^{\circ}$ ed. São Paulo: Expressão Popular, 2007. p. 23-33.

CORRÊA, Roberto Lobato. O espaço urbano. 2. ed. São Paulo: Ática, 1989

COSTA, Eduarda Marques da. Cidades médias. Contributos para sua definição. Revista Finesterra, XXXVII, 2002.

DAMIANI, Amélia Luisa. Cidades médias e pequenas no processo de globalização: apontamentos bibliográficos. 2006. Disponível em: <http://biblioteca.clacso.edu.ar/ar/libros/edicion/ lemos/08damiani.pdf>. Acesso em: out. 2012.

FEEDados. Consulta. Disponível em: <http://www.fee.rs.gov.br/feedados/consulta/sel_modulo_ pesquisa.asp>. Acesso em: jun. 2013.

HARVEY, David. A produção capitalista do espaço. São Paulo: Ed. AnnaBlume, 2001.

IBGE. Censo Demográfico. 2010. Disponível em: <censo2010.ibge.gov.br/>. Acesso em out.2013.

GOOGLE MAPS. Disponível em: <https://maps.google.com.br/ $\square>$. Acesso em: out. 2012.

GOOGLE STREET VIEW. O Google Maps com Street View permite explorar lugares no mundo todo através de imagens panorâmicas, em 360 graus, no nível da rua. Disponível em: < maps.google.com.br/ intl/pt-BR/help/maps/streetview/?utm...pt_BR $\square$ >. Acesso em: out. 2012.

$\mathrm{KOCH}$, Miriam Regina. Condomínios fechados: as novas configurações do urbano e a dinâmica imobiliária. 2008. Disponível em: <http://revistas.fee.tche.br/index.php/indicadores/article/viewFile/1582/1951>. Acesso em: out. 2013.

LENCIONI, Sandra. Sobre o conceito de cidade e de urbano. In: Revista Geousp, Espaço e Tempo. São Paulo, n. 24, 2008. p. 109-123.

SANTOS, Jânio; Reestrutura urbana x reestruturação da cidade: o caso de Salvador. 2008. Disponível em: < http://www.ub.edu/geocrit/-xcol/388.htm>. Acesso em: set. 2012.

SPOSITO, M. E. B. Cidades Médias: Reestruturação das Cidades e Reestruturação Urbana. In: SPOSITO, M. E. B. (Org). Cidades Médias: espaços em transição. $1^{\circ}$ ed. São Paulo: Expressão Popular, 2007. p. 233-253.

ZANCHET, Mateus João. A importância da BR 386 para o desenvolvimento do Vale do Taquari. 2013. Monografia (Departamento de Humanidades e educação - Curso de Geografia) - Universidade Regional do Noroeste do Estado do Rio Grande do Sul, 2013.

\section{Correspondência:}

\section{Eliza Bergamaschi}

E-mail: arquiteta.eliza@hotmail.com

Recebido em 01 de abril de 2014.

Geografia Ensino \& Pesquisa, v. 18, n.3 p. $07-26$, set./dez.. 2014

Os novos produtos imobiliários residenciais e as mudanças na organização espacial da cidade de Lajeado - RS
Revisado pelo autor em 15 de julho de 2014.

Aceito para publicação em 26 de agosto de 2014. 